\title{
PENANGGULANGAN KENAKALAN REMAJA DI SMP DAARUT TAUHID BOARDING SCHOOL
}

\author{
Hani Herlina dan Aceng Kosasih \\ Mahasiswa Program Studi Pendidikan Sosiologi FPIPS Universitas Pendidikan Indonesia \\ E-mail: hanni.herlina@gmail.com
}

\begin{abstract}
This study investigates the prevention of juvenile delinquency at a boarding school, i.e. Daarut Tauhid Secondary Boarding School. The aim of this study is to explore the preventive and repressive attempts made by the boarding school to overcome juvenile delinquency. This study employed a qualitative approach in the framework of a study case method. Observation, interview, and documentation were used as the data collection. The informants of this study consisted of Darut Tauhid Boarding School staffs, the students, and the people who lived around the school area. The results of this study show that the preventive and repressive attempt to prevent juvenile delinquency is made by maximizing the role of Islamic education.
\end{abstract}

Keywords : preventing, juvenile delinquency, boarding school

\begin{abstract}
ABSTRAK
Penelitian ini membahas secara mendalam mengenai penanggulangan kenakalan remaja yang dilakukan oleh siswa pada sekolah berasrama yaitu SMP Daarut Tauhid Boarding School. Penelitian ini bertujuan untuk mengetahui upaya preventif dan represif yang dilakukan sekolah berasrama dalam menanggulangi kenakalan remaja. Penelitian ini menggunakan pendekatan kualitatif dan metode studi kasus. Pengumpulan data dilakukan dengan teknik observasi, wawancara dan studi dokumentasi. Informan penelitian terdiri dari pihak sekolah, santri, dan masyarakat sekitar. Hasil penelitian ini menunjukkan bahwa upaya preventif dan represif penanggulangan kenakalan remaja oleh sekolah berasrama dilakukan dengan memaksimalkan peran pendidikan islam.
\end{abstract}

Kata Kunci : penanggulangan, kenakalan remaja, sekolah berasrama

\section{PENDAHULUAN}

Kenakalan remaja menjadi isu penting saat ini. Indonesia menjadi salah satu negara yang memiliki

tingkat kenakalan remaja lumayan tinggi. Terdapat beberapa kasus kenakalan yang dilakukan oleh 
remaja Indonesia di antaranya tawuran pelajar, hubungan seks di luar nikah, pencurian, bullying, penyalahgunaan narkotika dan obatobatan terlarang, geng motor dan lainnya. Seiring perkembangan IPTEK (Ilmu Pengetahuan dan Teknologi) dan pengaruh globalisasi saat ini memberikan berbagai permasalahan yang sangat beragam terutama di kalangan remaja di antaranya merebaknya isu moral seperti penggunaan narkotika dan obat-obatan terlarang, tawuran pelajar, pornografi, pemerkosaan, pencurian, aborsi, perampasan, penipuan, penganiayaan, perjudian, pelacuran, pembunuhan, permasalahan-permasalahan tersebut belum dapat diatasi secara tuntas dan maksimal (Hendriyenti, 2014, hlm. 204).

Beberapa kasus mengenai kejahatan atau kenakalan yang dilakukan oleh remaja tersebut dapat dengan mudah dijumpai di berbagai media massa, dan tidak jarang dapat ditemui di lingkungan sekitar. Permasalahan kenakalan remaja telah diakui menjadi masalah nasional pada tahun 1974 oleh Juvenile Justice and Delinquency Prevention Act (JJDPA), sehingga menjadi perhatian serius dari para pembuat kebijakan, masyarakat umum, dan pekerja sosial serta spesialis perawatan lainnya. Tidak hanya di Indonesia, kenakalan remaja juga merupakan masalah utama di banyak negara.

Masa remaja yang dikatakan sebagai masa transisi atau peralihan antara masa dewasa dengan anakanak, telah mampu menciptakan posisi remaja menjadi tidak stabil, agresif, sensitif, dan timbul berbagai konflik antara sikap dan nilai. Sehingga keadaan seperti ini mampu menimbulkan perilaku nakal pada remaja. Syafaat, Sahrani dan Muslih (2008, hlm.1) menjelaskan bahwa "salah satu masalah sosial tersebut adalah semakin menurunnya tatakrama kehidupan sosial dan etika moral remaja dalam praktik kehidupan, baik di rumah, sekolah, maupun lingkungan sekitarnya, yang mengakibatkan timbulnya sejumlah efek negatif di masyarakat yang akhir-akhir ini semakin merisaukan". Kemerosotan (dekadensi) moral yang terjadi pada remaja saat ini harus mendapat perhatian dan penanganan yang serius dari semua pihak, karena menurut Etzioni seorang remaja/anak pada hakikatnya masih memerlukan bimbingan agar dapat menjadi orang dewasa yang menyadari hak dan tanggung jawabnya sebagai anggota masyarakat yang baik (Budimansyah, 2015, hlm. 65).

Sekolah sebagai lembaga pendidikan merupakan salah satu pihak yang harus menangani permasalahan kenakalan pada remaja. Pada dasarnya lingkungan sekolah dapat membentuk kepribadian dan karakter siswa karena sekolah merupakan tempat belajar, tempat untuk membentuk karakter yang baik juga tempat untuk meniru sosok yang menjadi panutan/contoh/teladan bagi siswa (Samong, Suryadi dan Budimansyah, 2015, hlm. 79). Oleh karena itu, peran sekolah sangat dibutuhkan dalam membentuk karakter siswa untuk menjadi generasi bangsa yang unggul dan terhindar dari berbagai permasalahan.

Pembentukan karakter baik pada remaja dapat dilakukan dengan 
pendidikan agama. Sekolah yang memadukan pendidikan ilmiah dengan pendidikan moral dan akhlak serta sekolah yang menerapkan pendidikan agama secara kontinu selama 24 jam adalah manajemen sekolah berasrama (boarding school). Sekolah berasrama/boading school menurut Sayu, Ibrahim, dan Budjang, (2013) adalah "sekolah yang memiliki asrama, di mana para siswa hidup; belajar secara total di lingkungan sekolah. karena itu segala jenis kebutuhan hidup dan kebutuhan belajar disediakan oleh sekolah". Pendidikan agama dan pendidikan umum secara utuh didapatkan oleh siswa di sekolah. Siswa tinggal di asrama dan semua elemen yang ada di sekolah ikut terlibat dalam proses pendidikan selama 24 jam. Sehingga dengan konsep pendidikan yang dimiliki oleh boarding school diharapkan dapat menghasilkan keluaran yang dapat bersaing secara global namun tetap dibekali ilmu agama. Dengan bekal ilmu agama yang dimiliki siswa akan dapat menilai hal-hal yang boleh dilakukannya dan tidak boleh dilakukannya sesuai dengan nilai dan norma yang berlaku di masyarakat.

Karena itu, sistem pendidikan boarding school diharapkan dapat mengatasi permasalahan kompleks di dunia pendidikan seperti yang dikatakan oleh Sastra Juanda (Kepala sub. Direktorat Kesiswaan Direktorat Pendidikan Madrasah di Direktorat Jenderal Pendidikan Islam Kemenag RI) (dalam Bahtiar, 2013) bahwa, "sistem pendidikan boarding school ini juga menjadi salah satu konsep yang digagas oleh kemenag $\mathrm{RI}$ dalam rangka menanggulangi dan mencegah terjadinya degradasi moral pada remaja sebagai dampak dari globalisasi". Konsep ini dipandang tepat dalam memproteksi kenakalan remaja yang terjadi. Seperti yang diungkapkan Sudarsono dalam Syafaat dkk. (2008) bahwa

Bagi anak remaja, sangat diperlukan adanya pemahaman, pendalaman serta ketaatan terhadap ajaran-ajaran agama yang dianut. Kenyataan seharihari menunjukkan bahwa anakanak remaja yang melakukan kejahatan sebagian besar kurang memahami norma-norma agama, bahkan mungkin lalai menunaikan perintah-perintah agama. (hlm. 3)

Oleh karena itu, penelitian tentang penanggulangan kenakalan remaja yang dilakukan oleh sekolah berasrama yang memiliki manajemen dan kurikulum berbeda dengan sekolah lainnya sangat diperlukan sebagai upaya untuk mencegah dan mengurangi tingkat kenakalan remaja yang marak terjadi dewasa ini.

\section{METODE}

$\begin{array}{lrr}\text { Penelitian ini merupakan } & \text { menelitian kualitatif } & \text { dengan }\end{array}$ menggunakan metode studi kasus. Penelitian dilakukan di SMP Daarut Tauhid Boarding School yang beralamat di Jl. Gegerkalong Girang No. 38 Bandung. Pemilihan lokasi penelitian karena SMP Daarut Tauhid Boarding School merupakan sekolah berasrama yang menerapkan kurikulum diknas dan kurikulum khas pesantren Daarut Tauhid dan diperoleh data awal dari Wakabid Kesiswaan yaitu Pak Bagja Dani Maghribi, bahwa terdapat beberapa jenis kenakalan remaja yang 
dilakukan oleh peserta didik. Informan penelitian sebanyak 22 informan, terdiri dari sebelas orang pihak sekolah, tujuh orang santri akhwat, tiga orang santri ikhwan, dan masyarakat sekitar. Pihak-pihak tersebut dianggap mempunyai informasi yang peneliti butuhkan untuk mengungkapkan permasalahan yang telah dirumuskan.

Hasil penelitian yang diperoleh melalui teknik observasi, wawancara dan studi dokumentasi, kemudian dianalisis dengan menggunakan konsep dari Miles dan Huberman yang terdiri dari teknik reduksi data reduction), penyajian data (data display), dan penarikan kesimpulan atau verifikasi (conclusion drawing verification) (1992, hlm. 16-20). Setelah dianalisis, data yang diperoleh diperiksa keabsahannya dengan cara perpanjangan pengamatan, triangulasi dan menggunakan bahan referensi.

\section{HASIL DAN PEMBAHASAN}

Berdasarkan hasil penelitian, upaya penanggulangan kenakalan remaja terdiri dari upaya pencegahan (preventif) dan upaya penanganan santri yang berbuat nakal (represif). Tidak seperti yang dikemukakan oleh Syafaat dkk. (2008, hlm. 139-152) bahwa usaha penanggulangan kenakalan dapat dikelompokkan menjadi lima sebagai berikut "tindakan preventif, tindakan represif, tindakan kuratif, tindakan hukuman, tindakan rehabilitasi dan pembinaan remaja". Meskipun terdapat perbedaan, namun upaya penanggulangan yang dilakukan oleh sekolah telah mencakup kelima upaya tersebut, namun tindakan kuratif, hukuman, rehabilitasi dan pembinaan disebutkan dalam upaya represif yang dilakukan oleh sekolah dalam menangani santri yang telah melakukan kenakalan.

Tindakan preventif menurut Nasir (1999, hlm. 90) adalah "suatu tindakan yang bertujuan mencegah timbulnya kenakalan-kenakalan". Hal ini sesuai dengan hasil penelitian bahwa SMP Daarut Tauhid Boarding School mempunyai pola preventif untuk mencegah terjadinya kenakalan santri. Upaya preventif dalam mencegah kenakalan santri yang telah dilakukan oleh pihak sekolah/asrama di antaranya pembuatan dan sosialisasi tata tertib; mengadakan wawancara kepada calon santri dan orangtua saat proses seleksi masuk; melakukan absensi pada setiap kegiatan; pemberian motivasi dan nasihat islami; mengadakan kegiatan keagamaan seperti halaqoh dan kajian; melakukan pendataan santri yang berpotensi melakukan kenakalan; pemberian teladan/contoh yang baik oleh pihak sekolah; terjun langsung ke lapangan untuk melakukan sweeping/sidak; melakukan pendekatan secara personal dengan santri; dan menempel peraturan di area sekolah dan asrama.

Peneliti mempunyai pandangan yang sama dengan jurnal yang berjudul "Faktor Penyebab Dan Pengentasannya Terhadap Pelanggaran Tata Tertib" dari Triwurhana Nilasari Putri (2014) menyatakan bahwa usaha preventif dalam menangani pelanggaran siswa menitikberatkan pada pembinaan moral dan membina kekuatan mental anak remaja. Karena dari hasil wawancara dengan pihak sekolah bahwa SMP Daarut 
Tauhid Boarding School mengadakan berbagai kegiatan keagamaan di asrama seperti halaqoh, lailatul hisab, dan kajian sebagai upaya pembinaan moral santri melalui pendidikan islami dalam rangka mencegah perilaku nakal santri. Selain mengadakan kegiatan keagamaan juga memberikan berbagai nasihat dan motivasi islami yang disampaikan secara personal kepada santri maupun melalui berbagai kegiatan keagamaan. Penyelenggaraan berbagai kegiatan keagamaan juga sebagai upaya sekolah/asrama dalam membina mental santri untuk menjadi pribadi yang selalu berjuang dalam kebaikan. Pembinaan mental santri dilaksanakan juga melalui proses wawancara pada saat seleksi masuk untuk menguji kesiapan santri hidup di lingkungan sekolah berasrama.

Upaya penanggulangan kenakalan remaja lainnya melalui upaya represif. Seperti yang dikatakan oleh Syafaat dkk. (2008, hlm. 141) upaya represif merupakan "pemberian sanksi atau hukuman ketika seseorang melakukan pelanggaran. Tindakan represif pada dasarnya merupakan pencegahan setelah terjadi pelanggaran". Sehingga upaya represif dapat dikatakan sebagai upaya yang dilakukan untuk mengatasi kenakalan remaja yang terlanjur sudah terjadi atau terlanjur sudah dilakukan oleh remaja dengan tujuan agar remaja tidak melakukan kenakalan lagi.

Berdasarkan hasil penelitian, upaya represif yang dilakukan oleh SMP Daarut Tauhid Boarding School dalam menangani santri yang melakukan kenakalan di antaranya; memberikan teguran; memberikan nasihat islami kepada santri sesuai dengan jenis kenakalan yang dilakukan; memberikan konsekuensi berupa hukuman fisik dan hukuman islami; bekerjasama dengan orangtua santri dalam menangani kenakalan; mengadakan forum wali kelas dan wali asuh; mengawasi secara ketat santri yang melakukan kenakalan; melibatkan santri dalam menentukan konsekuensi yang akan diterimanya sebagai bentuk tanggung jawab; melibatkan santri yang melakukan kenakalan untuk mendisiplinkan santri yang lain; memberikan kegiatan positif yang cukup padat; melibatkan santri yang melakukan kenakalan dalam berbagai kegiatan positif seperti pertunjukan keterampilan; dan memaksimalkan peran pendidikan agama islam.

Upaya represif yang dilakukan oleh pihak SMP Daarut Tauhid Boarding School, lebih banyak melakukan upaya represif yang memaksimalkan peran pendidikan islami yang terlihat dari kegiatan keagamaan, pemberian motivasi dan nasihat islami yang berasal dari hadits dan ayat Al-Quran berkaitan dengan jenis kenakalan yang dilakukan, dan bentuk konsekuensi yang diterima santri mengandung pendidikan islam seperti menulis istighfar, membaca dan menulis ayat Al-Quran, shalat taubat, karena bentuk kenakalan yang banyak dilakukan oleh santri tidak melanggar undang-undang namun hanya sebatas melanggar tata tertib dan melanggar syariat islam. 
Pihak sekolah juga melakukan upaya kerjasama dengan orangtua santri yang berbuat nakal dalam menangani kasus kenakalan remaja. Kerjasama yang dilakukan dapat berupa keterlibatan orangtua santri dalam menentukan metode penanganan yang akan dilakukan oleh sekolah, juga keterlibatan orangtua untuk membantu sekolah dalam mendampingi santri saat melakukan proses perubahan positif. Keterlibatan orangtua dalam menangani kenakalan remaja di sekolah sangat penting. Pentingnya keterlibatan orangtua dalam membimbing anak sebagai rangka mencapai tujuan pendidikan yang telah ditentukan sekolah, karena sikap, perilaku, prestasi anak tercermin dari sikap dan gaya orangtua, ketika adanya ketidakseimbangan pola pendidikan di antara anggota keluarga akan menjadi sumber permasalahan bagi anak terutama remaja (Dewi dan Budimansyah, 2015, hlm. 102). Hal ini merupakan fakta yang sering dirasakan oleh pihak sekolah, ada beberapa kenakalan remaja yang dilakukan santri disebabkan oleh pola pendidikan dan pola asuh orangtua yang kurang tepat. Oleh karena itu orangtua harus dapat memilih tipologi pola asuh yang tepat terhadap anak. Mengenai hal ini, peneliti mempunyai pendapat yang sama dengan Jurnal yang berjudul "A Typology of Father Parenting in The Migrant Workers Family and Effect on Character of Children" oleh Wilodati, Budimansyah, Adiwikarta dan Ruyadi (2015) yang menyatakan bahwa setiap tiplologi pola asuh akan menghasilkan karakter anak yang berbeda, sehingga orangtua harus memilih tipologi pola asuh yang tepat untuk membentuk karakter yang baik pada anak.

Pengawasan secara ketat senantiasa dilakukan oleh sekolah sebagai upaya penanganan kenakalan yang dilakukan oleh santri, karena pada dasarnya usia remaja sangat membutuhkan arahan dan bimbingan dari orang dewasa. Hal ini sesuai dengan teori kontrol pada teori penyimpangan yang berperspektif sosiologis yang dijelaskan oleh Setiadi dan Kolip (2011, hlm. 241-243) bahwa "penyimpangan merupakan hasil dari kekosongan kontrol atau pengendalian sosial. Teori ini dibangun atas dasar pandangan bahwa setiap manusia cenderung untuk tidak patuh pada hukum atau memiliki dorongan untuk melakukan pelanggaran hukum". Dari teori tersebut terlihat bahwa manusia memiliki dorongan atau kecenderungan untuk melanggar hukum atau ketentuan, begitu pun pada remaja yang memiliki karakteristik yang unik sangat rentan untuk melanggar peraturan. Sehingga ketika pengawasan atau kontrol yang dilakukan kurang, maka remaja akan semakin menyimpang dari yang seharusnya.

Upaya represif lainnya dengan melibatkan santri yang melakukan kenakalan pada berbagai kegiatan positif seperti pertunjukan keterampilan tari saman. Berdasarkan hasil wawancara dengan pihak sekolah bahwa upaya ini memberikan pengaruh cukup besar dalam mengembalikan kepercayaan diri santri yang melakukan kenakalan serta 
memberikan kebanggaan dan kesan positif kepada orangtua yang bersangkutan terhadap anaknya.

Pemberian hukuman fisik kepada santri yang melakukan kenakalan tidak sering dilakukan oleh sekolah. Karena menurut keterangan salah satu pihak sekolah dari hasil wawancara bahwa hukuman fisik tidak memberikan pengaruh banyak atau memberikan efek jera kepada santri, hukuman fisik hanya memberikan efek cape dan lelah kepada santri. Oleh karena itu, pihak sekolah lebih banyak memberikan konsekuensi berupa hukuman yang mengandung kebaikan seperti menulis istighfar, membaca dan menghafal Al-Quran, shalat taubat, dan lainnya. Mengenai hal ini dibenarkan oleh jurnal yang berjudul "The Relationship between Vigorous Physical Activity and Juvenile Delinquency: A Mediating Role for Self-Esteem?"oleh Guy E.J Faulkner, Erdward M. Adlaf, Hyacinth M. Irving, Kenneth R. Allison, John J.M. Dwyer dan Jack Goodman (2007) yang menyatakan bahwa aktivitas fisik bukanlah solusi untuk mengurangi kenakalan remaja, karena aktivitas fisik yang kuat terkait dengan perilaku nakal hanya dikalangan remaja laki-laki. Sehingga peneliti berpendapat bahwa hukuman fisik kepada remaja yang melakukan kenakalan bukanlah metode penanganan yang tepat, karena pemberian hukuman fisik kepada remaja harus dilakukan dengan pertimbangan yang matang, sehingga kemungkinan buruk yang menjadi dampak dari pemberian hukuman fisik tersebut tidak akan terjadi.
SMP Daarut Tauhid Boarding School sebagai sekolah berasrama yang mempunyai dasar pendidikan islami yang tinggi menjadikan pendidikan agama islam sebagai dasar dalam menentukan sebuah keputusan seperti menentukan bentuk konsekuensi yang akan diterima oleh santri yang melakukan kenakalan. Berdasarkan hasil wawancara bahwa pendidikan agama islam sangat berperan besar dalam menentukan keberhasilan upaya penanggulangan kenakalan remaja yang dilakukan oleh sekolah. Hasil penelitian ini sesuai dengan jurnal yang berjudul "Peranan Pondok Pesantren Dalam Mengatasi Kenakalan Remaja (Studi kasus di Pondok Pesantren Al-Muayyad Surakarta)" dari Suyono, Herimanto dan Sri Wahyuni (Tanpa Tahun) yang menyatakan bahwa pondok pesantren sangat berperan dalam mengatasi kenakalan remaja, karena memberikan pendidikan islam kepada santri untuk dipraktekkan dalam kehidupan sehari-hari. Maka santri dapat berfikir rasional dan mampu membedakan hal yang baik dan hal yang buruk. Sehingga anak akan cenderung berbuat positif dan sesuai dengan ajaran islam. Berdasarkan jurnal tersebut, peneliti berpendapat bahwa pola penanggulangan kenakalan remaja yang dilakukan oleh SMP Daarut Tauhid Boarding School dengan memaksimalkan peran pendidikan islami dalam bentuk konsekuensi yang akan diterima santri yang melakukan kenakalan dapat dikatakan upaya penanggulangan kenakalan remaja yang tepat, karena pendidikan agama merupakan hal 
yang paling utama dalam mengendalikan dan membentuk perilaku positif remaja.

Berbagai

upaya

penanggulangan kenakalan remaja yang terdiri dari upaya preventif dan represif dengan memaksimalkan peran pendidikan islam oleh SMP Daarut Tauhid Boarding School bertujuan untuk membentuk pribadi remaja yang memiliki kesadaran moral. Sesuai dengan hasil wawancara dengan salah satu pihak sekolah bahwa tujuan dari semua penyelenggaraan upaya penanggulangan kenakalan remaja adalah agar santri memiliki kesadaran bahwa apa yang telah dilakukannya merupakan perbuatan salah, sehingga memiliki kemauan untuk berubah ke arah yang lebih baik. Sesuai dengan pendapat dari Selly Tokan dalam Hendriyenti (2014) bahwa

Remaja dikatakan bermoral jika mereka memiliki kesadaran moral yaitu dapat menilai hal-hal yang baik dan buruk, hal-hal yang boleh dilakukan dan tidak boleh dilakukan serta hal-hal yang etis dan tidak etis. Maka remaja yang bermoral akan tampak dari perilakunya yang baik, benar dan sesuai dengan etika. (hlm. 205)

Berdasarkan pendapat Hendriyenti di atas bahwa remaja yang memiliki kesadaran moral dapat menilai halhal yang boleh dilakukannya dan tidak boleh dilakukannya sesuai dengan nilai dan norma yang berlaku di masyarakat. Sehingga kesadaran moral ini dapat menjadi benteng untuk tidak melakukan hal negatif. Kesadaran moral dapat diberikan melalui pendidikan islami. Pihak sekolah/asrama sering memberikan pengetahuan islam kepada santri melalui berbagai kegiatan keagamaan atau nasihat secara personal. Hal tersebut merupakan proses pembelajaran yang diselenggarakan oleh sekolah/asrama dalam rangka membentuk kesadaran moral pada pribadi santri. Hal ini telah terbukti dari hasil penelitian jurnal yang berjudul "Implementing Value Clarification Technique to Improve Enviromental Awareness among Pre-service Chemistry Teacher" dari Sulastri, Budimansyah dan Sopandi (2015) bahwa kesadaran lingkungan dapat terbentuk setelah proses belajar yang dilakukan oleh siswa, sehingga memiliki pertimbangan moral yang bijak dalam bertindak melawan berbagai permasalahan lingkungan.

Tentunya ini menjadi penguatan tentang pentingnya pendidikan dan pembelajaran pada siswa untuk menanamkan moral salah satunya melalui pendidikan islam yang senantiasa diberikan oleh pihak sekolah/asrama di SMP Daarut tauhid Boarding School agar terhindar dari berbagai perilaku negatif pada remaja. Sehingga peneliti berharap dengan pendidikan agama salah satunya islam dapat membantu banyak dalam menciptakan remaja yang unggul dan terhindar dari berbagai permasalahan.

\section{SIMPULAN}

Upaya penanggulangan kenakalan remaja yang dilakukan oleh santri terdiri dari upaya preventif dan represif. Upaya preventif untuk mencegah remaja melakukan kenakalan serta upaya represif untuk 
mengatasi remaja yang sudah melakukan kenakalan. Pelaksanaan upaya preventif dan represif dalam menanggulangi kenakalan yang terjadi dengan memaksimalkan peran pendidikan islam yang terlihat dalam bentuk konsekuensi yang diterima remaja yang melakukan kenakalan.

\section{DAFTAR RUJUKAN}

\section{Buku}

Miles, M.B. \& Huberman, M. (1992). Analisis Data Kualitatif. Jakarta: Penerbit Universitas Indonesia

Nasir, S.A. (1999). Peranan Pendidikan Agama Terhadap Pemecahan Problema Remaja. Cetakan I. Jakarta: Kalam Mulia Setiadi, E.M. \& dan Kolip, U. (2011). Pengantar Sosiologi

Pemahaman Fakta dan Gejala Permasalahan Sosial: Teori, Aplikasi dan Pemecahannya. Jakarta: Kencana

Syafaat, A., Sahrani, S., \& Muslih (2008). Peranan Pendidikan Agama Islam Dalam mencegah Kenakalan Remaja (Juvenile Delinquency). Jakarta: PT Rajagrafindo Persada

\section{Jurnal}

Budimansyah, D. (2015). Fundamental Sociological Symptoms as a Source Occurance of Turbulence in Indonesian Society During The Post-Reform. 1st UPI International Conference on Sociology Education, hlm. 6366.

Dewi P.F, K. A. P \& Budimansyah, D. (2015). The Community-Based Value Education to Develop
Environmental Awareness

Caharacters for Elementary Schools Students. 1st UPI International Conference on Sociology Education, hlm. 102106.

Faulkner, G.E.J., Adlaf, E.M., Irving, H.M., Allison, K.R., Dwyer, J.J.M., \& Goodman, J. (2007). The Relationship etween Vigorous Physical Activity and Juvenile Delinquency: A Mediating Role for SelfEsteem?. Journal of Behavioral Medicine, 30 (2), hlm. 155-163.

Hendriyenti. (2014). Pelaksanaan Program Boarding School Dalam Pembinaan Moral Siswa di SMA Taruna Indonesia Palembang. Jurnal Ta'dib, 19 (2), hlm. 203-226.

Putri, T.N. (2014). Faktor Penyebab dan Pengentasannya terhadap Pelanggaran Tata Tertib. Jurnal Ilmiah Pendidikan Bimbingan dan Konseling, 2 (1), hlm. 1-13

Samong, F., Suryadi, A., \& Budimansyah, D. (2015). The Development of Character Education in Primary Schools Through the Enhancement of School Culture. 1st UPI International Conference on Sociology Education, hlm. 7779.

Sayu, J. A., Ibrahim, M. Y., \& Budjang, G. (2013). Adaptasi Sosial Siswa Kelas X Pada Boarding School SMA Taruna Bumi Khatulistiwa. Jurnal Pendidikan dan Pembelajaran, 2 (9).

Sulastri, Budimansyah, D., \& Sopandi, W. (2015). Implementing Value Clarification 
Technique to Improve Enviromental Awareness among Pre-Service Chemistry Teacher. 1st UPI International Conference on Sociology Education, hlm. 190-193.

Suyono, Herimanto, \& Wahyuni, S.

(Tanpa Tahun). Peranan Pondok Pesantren dalam Mengtasi Kenakalan Remaja (Studi kasus di Pondok Pesantren Al-Muayyad Surakarta). Jurnal, hlm. 1-18.

Wilodati, Budimansyah, D., Adiwikarta, S., \& Ruyadi, Y. (2015). A Typology of Father Parenting in The Migrant Workers Family and Effect on Character of Children. 1st UPI International Conference on Sociology Education, hlm. 223227.

\section{Internet}

Bahtiar, R. (2013). Kementerian Agama Terapkan Konsep Islamic Boarding School. [Online]. Diakses dari http://pzhgenggong.or.id/132/ke menterian-agama-terapkankonsep-islamic-boardingschool.html 